\title{
A film adaptation of Stephen King's novella "Rita Hayworth and Shawshank Redemption" (1982) as an example of a multimodal translation pattern
}

\begin{abstract}
Recently, I came across the statement that ,adaptation is a procedure for the translation of the film” (Post). Adaptation reaches not only the increasing circles of the cinema or art, but also our lives, and the very concept of adaptation undergoes constant expansion. The main goal of this article is to show that film adaptation is an example of a multimodal translation pattern. As a result, we receive a completely new text, which is a film, in contrast to its literary prototype. To show that a film adaptation is an example of a multimodal translation pattern I will discuss it from a linguistic point of view. The article will often refer to modality or multimodal text. I will also present a small part of the research conducted on the film from a linguistic point of view at the Philology University (Wyższa Szkoła Filologiczna) in Wrocław.
\end{abstract}

Keywords: multimodal translation, monomodal text, multimodal text, linguistic sign, cinematic sign

\section{Introduction}

Adaptation is a transposition. To what extent the new work is an adaptation is a relative question, because there are no strictly defined limits determining percentage wise, or in any other way, which work is still an adaptation and which is not an adaptation anymore.

„A film adaptation is of course a sort of translation. It is a reading, an interpretation of a literary work which is its foundation, through the film system of signs" (Hopfinger, 1974: 81). 
Below, I will develop the issue of film adaptation as a pattern of a multimodal translation. However, in order to explain clearly what a multimodal translation is, I will first define what a text, modality, monomodal text and multimodal text are.

\title{
2. Definitions
}

Post (2017: 19) presents a fairly common formula that film is a text. Author claims it is represented by James Monaco in How to read a film (2009), Tomasz Gruszczyk in Reading a film - watching literature (2015), Janina Wildfeuer and John Beatman in Film Text Analysis: New Perspectives on the Analysis of Filmic Meaning (2017).

The word ,mode" means a single mode or a manner, so if we are talking about a monomodal text, we mean the expression of information exclusively by means of one semiotic code or one modality. For example, we consider any literary work as a monomodal text, unless it has been provided with additional drawings.

A multimodal text is a text which contains at least two modalities. For example, a cartoon is a multimodal text because it contains visual modality in the form of pictures, as well as a linguistic modality in the form of individual letters, words, sentences or events.

A film is also a multimodal text because it contains three modalities: image, linguistic and background sounds. A film adaptation is therefore made of three codes, i.e. it employs three modalities. One moment we see movement (the 1st mode), we listen to the conversation of the characters (the 2nd mode), and listen to the accompanying music, accompanied by sounds of nature or additional sounds (the 3 rd mode as a whole). According to Post (2017: 41), it is the ,visual modality that is the elementary and basic semiotic means of the film complemented by linguistic and sound modalities co-operating with it".

It should also be noted that this is a great simplification (accepted only for research purposes during the $\mathrm{PhD}$ seminar) that we express literature and spoken language only with the use of one semiotic code. For instance, literature often includes additional modality in a form of useful diagrams, the same like our verbal utterances have always been accompanied by gestures. However, as I have already mentioned - for the purpose of research on the multimodal text, during the seminar we adopted the following diagram showing the intensity of modalities in all available texts.

Various types of texts on the modal saturation scale

a) written text - monomodal - linguistic modality

b) spoken text - multimodal - linguistic modality + gestures

c) cartoon - multimodal - visual modality + linguistic modality

d) film - multimodal - visual + sound + linguistic modality

\author{
MonoMod (-)

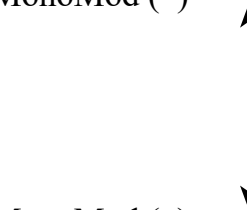

MonoMod (-)

Diagram 1.0. Places of selected types of texts on the scale of modal saturation (adapted from: Post, 2017: 20) 


\section{Multimodal translation}

Below, I will present an example of a multimodal translation in the film adaptation The Shawshank Redemption (1994), i.e. I will present specific sentences from the book The Shawshank Redemption (2001) (the original title is Rita Hayworth and Shawshank Redemption 1982) describing a given subject or event which were initially written only with linguistic signs and then expressed in a different way by means of cinematic signs (also known as multimodal signs).

For example, a certain stone is described in the book as follows: ,...I saw the rock. No mistake. Black glass and as smooth as silk. A rock with no earthly business in a Maine hayfield. (Shawshank Redemption, 2001: 103) However, in the film it looked like this:

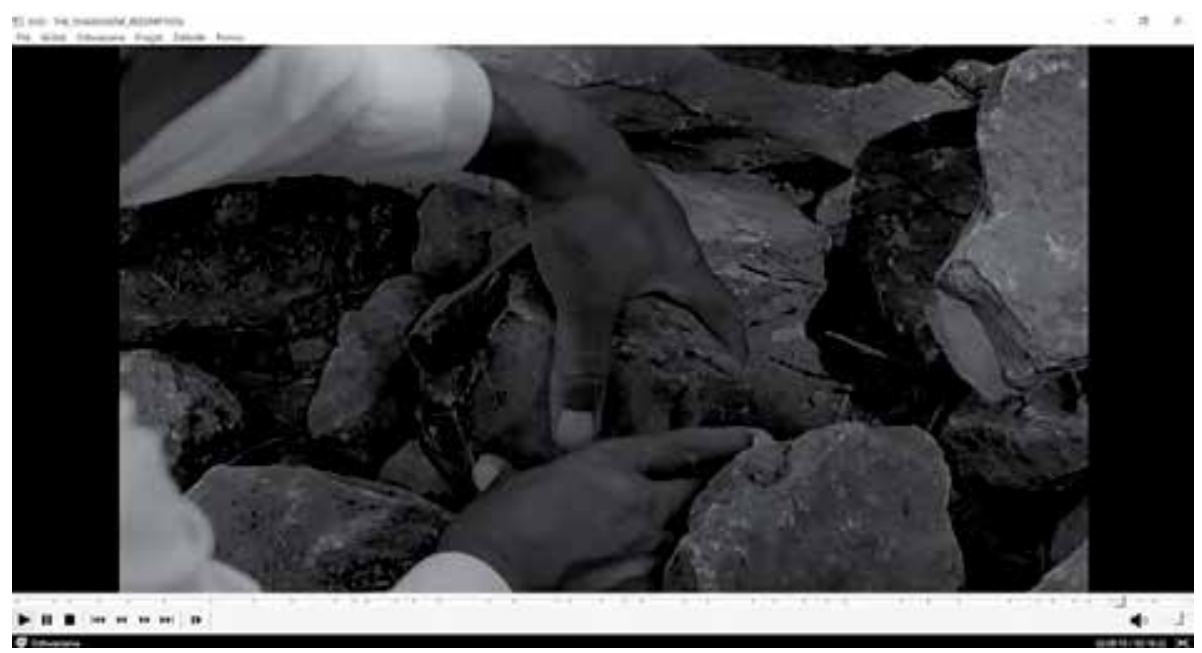

2:08:19 sec

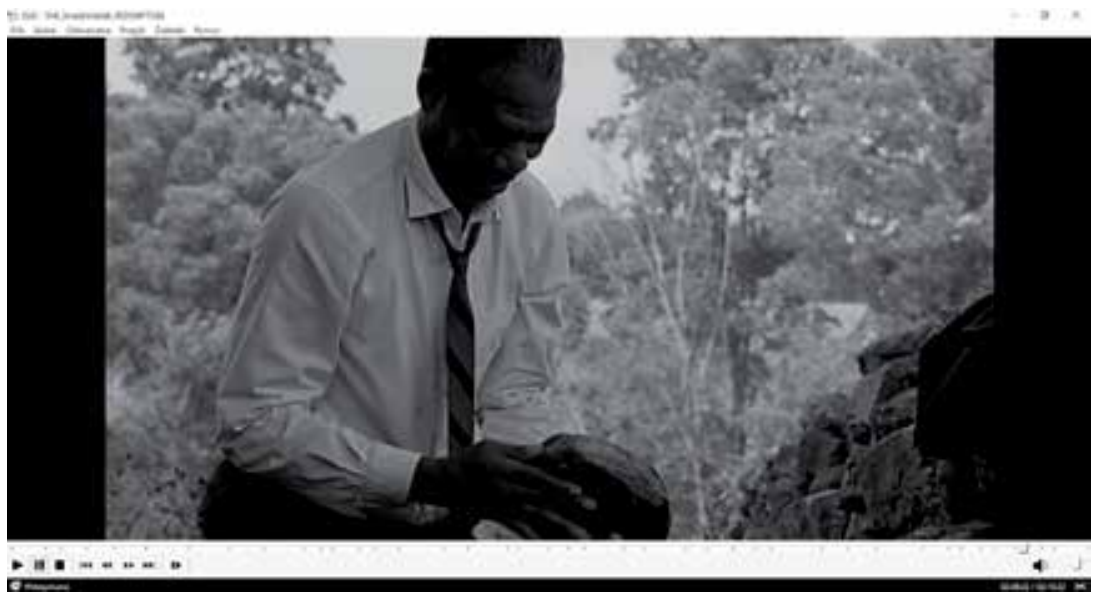

2:08:22 sec

Frames 2.0. - 2.1. from the movie The Shawshank Redemption (1994) 
According to Maryla Hopfinger (1974), the cinematic signs are not uniform, on the contrary, in comparison with linguistic signs, they have a continuous and indiscrete nature.

Imagine, for example, a movie scene or an advertisement and in it, appearing in the distance, any object or product with a company logo. It seems to me that no one will have a problem recognising what product or company the ad is referring to. Below, are two examples of cinematic signs.


Commercial and business logos 3.1.-3.2. of the manufacturer of Michelin tyres and the German company producing footwear and sportswear Adidas AG

For a better presentation of what a multimodal translation is, I will present the difference between a monomodal linguistic sign and a multimodal cinematic sign.

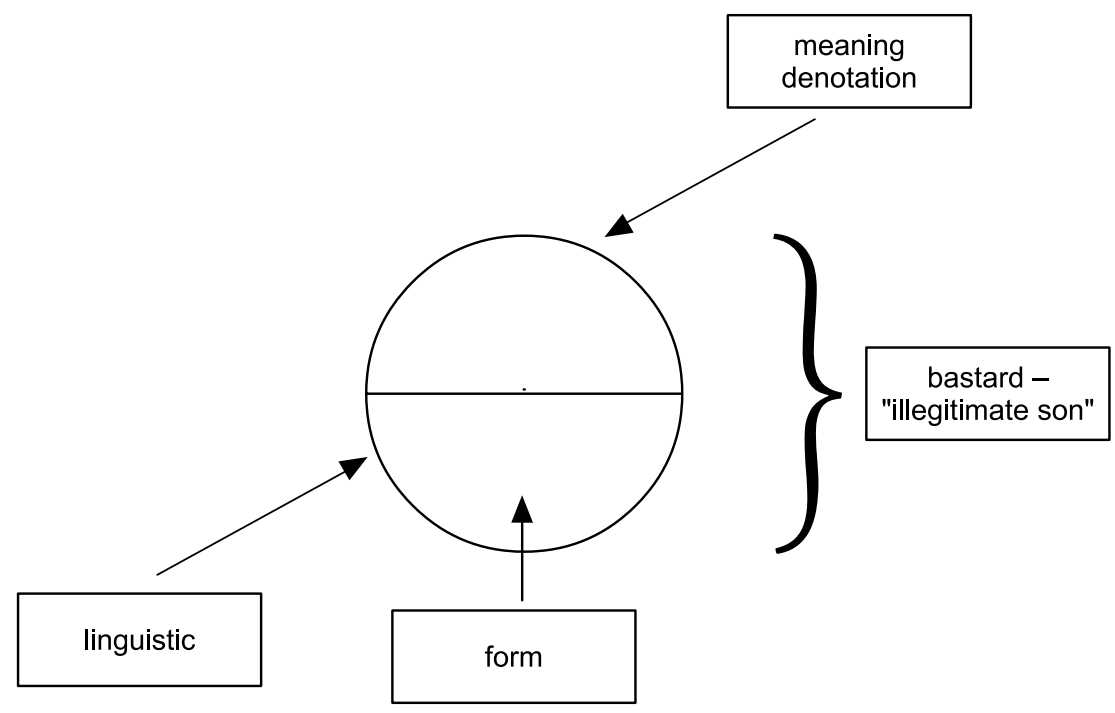

Diagram 1.1. A monomodal linguistic sign (adapted from: Post, 2017: 150) 
A linguistic sign according to Ferdinand de Saussure is always made of two elements: a) a signifier is a physical representation - an image, a road sign, a photograph, a symbol, a letter (morpheme), it can also be an acoustic representation (for example, a particular phone).

b) a signified, that is, a concept associated with it, which may well be an abstract concept, implying a meaning (or denotation - containing features of a given class of objects).

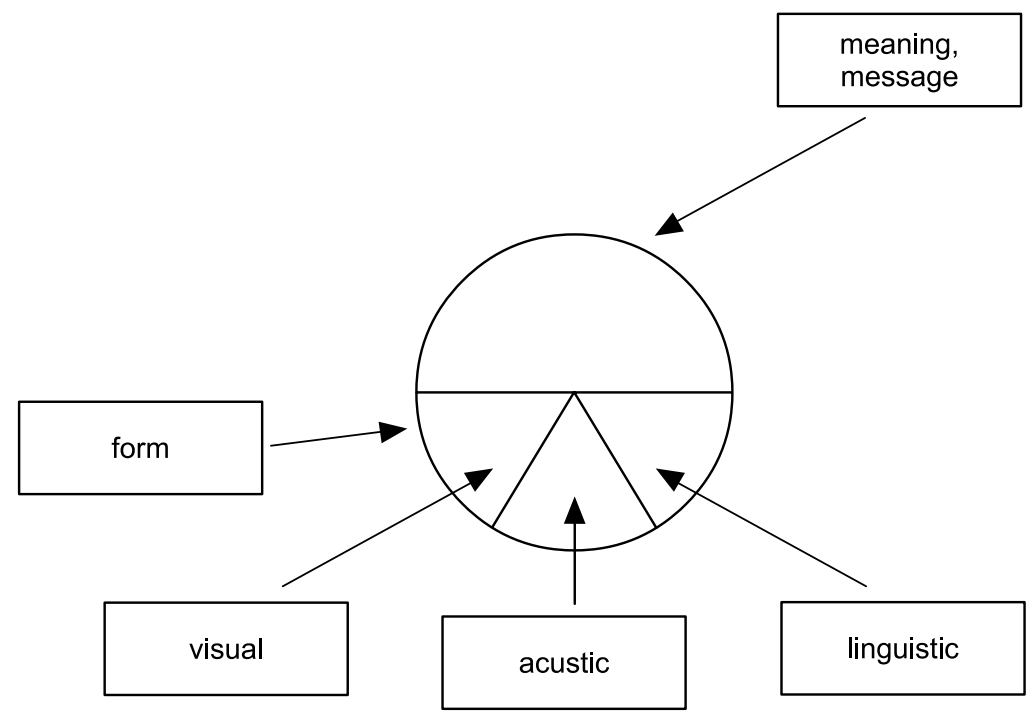

Diagram 1.2. Multimodal cinematic sign (adapted from: Post, 2017: 150)

However, a cinematic sign may be, depending on the film scene or a particular view of it, for example: a given object, stage prop, hero, individual sound, for example a thunderclap during a storm or any word uttered. While analysing the above diagram, please note that a cinematic sign has the features of both a linguistic and a non-linguistic sign.

For a better understanding, let's also analyse a purely hypothetical sentence or event from the book, described in a few sentences. For example, the protagonist's escape from prison, to which a comment would be attached: "The storm was cursed, it rained and thundered all night." After which we see an escapee on the screen, crawling through a sewage pipe and coming out of it, in the middle of a storm with lightning flashes and thunderbolts, all accompanied by the voice of the narrator. 


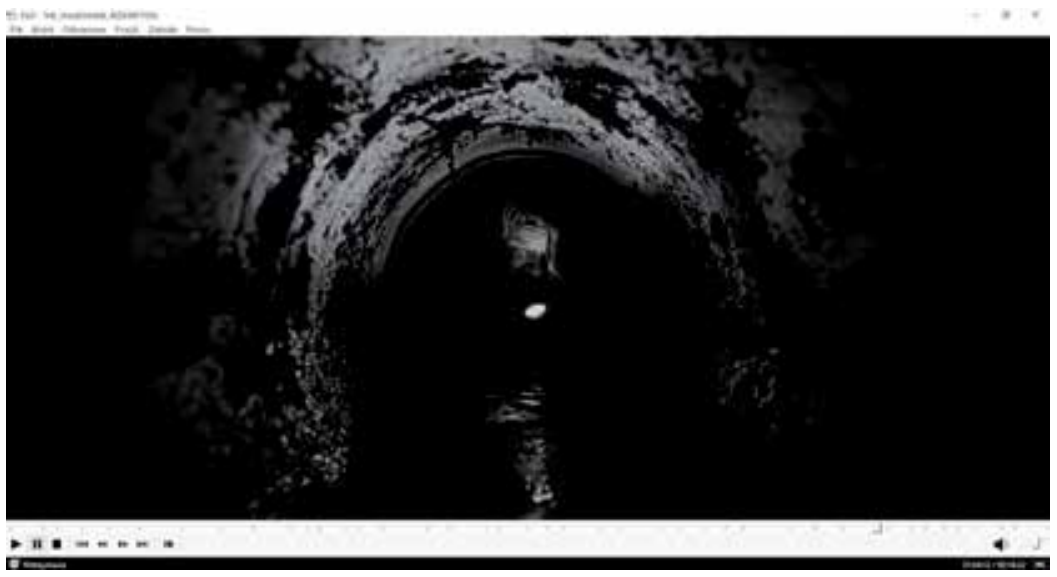

$1: 54: 12 \mathrm{sec}$

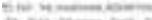
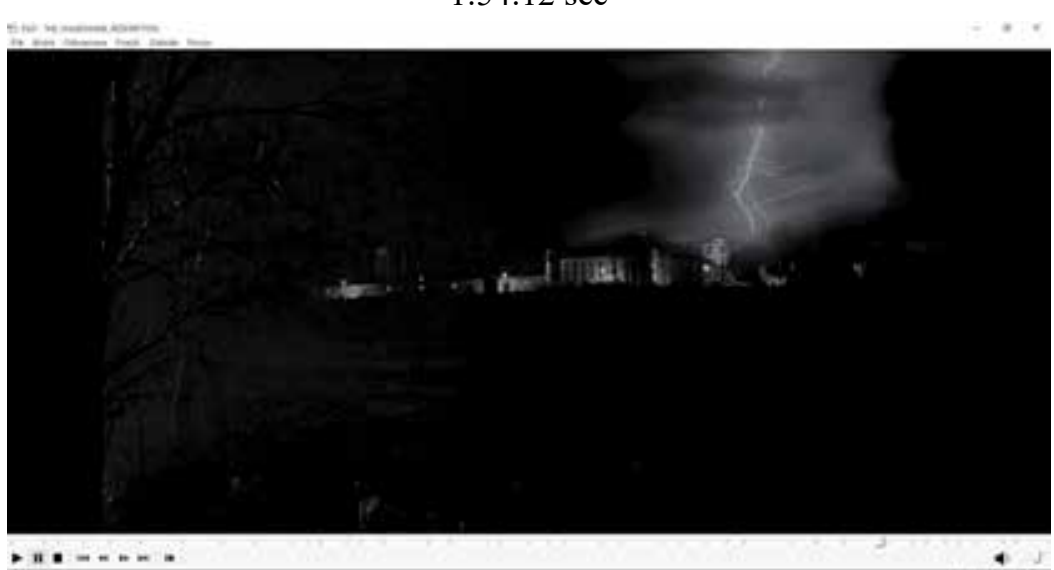

n: $n=\ldots+\infty$ $4 \quad j$

1:54:26 sec

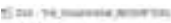



十 $4 \quad 1$

1:54:33 sec 




$1: 54: 34 \mathrm{sec}$

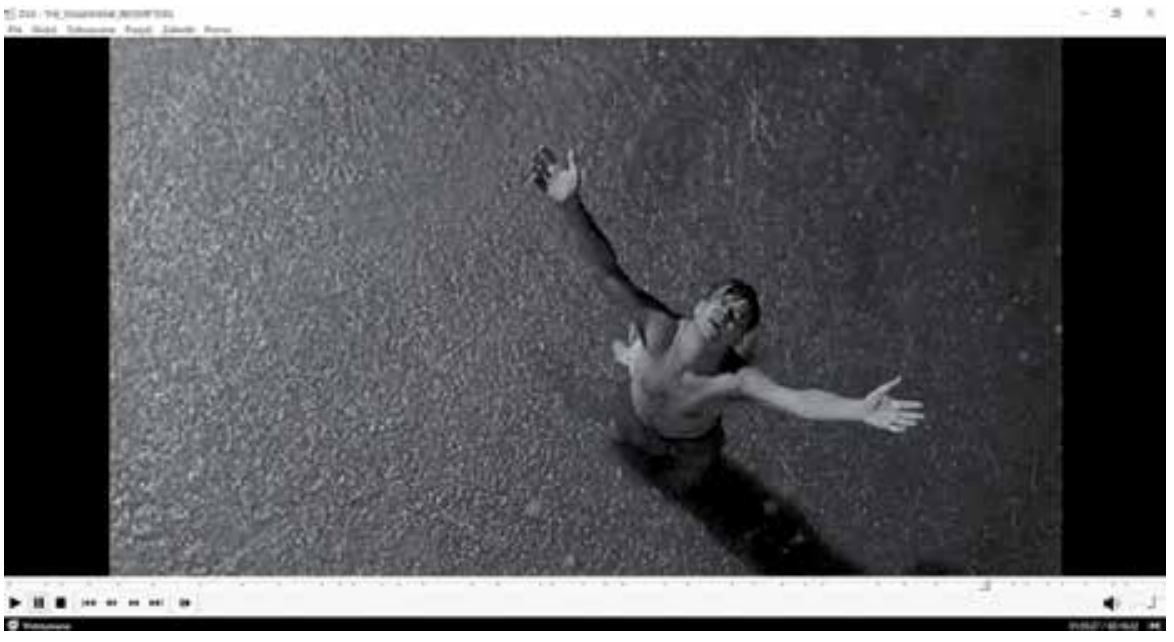

$1: 55: 27 \mathrm{sec}$

Frames 2.3.-2.7. from the movie The Shawshank Redemption (1994)

In the above scenes a multimodal translation has been used. A sentence which would be written with a single semiotic code (one modality) would be expressed on the screen by means of three modalities. For example, the word storm, which would appear in the monomodal text, would be expressed by means of at least a cinematic sign, such as: lightning flashes and thunderclaps, raindrops or rustling trees.

In conclusion, using the cinematic signs (multimodal signs), that is, by using a multimodal translation, we can not only see every event recorded in the book but also hear it at the same time. 


\section{Summary}

In the above article I showed that the film adaptation of the story Rita Hayworth and Shawshank Redemption (1982) is an example of a multimodal translation pattern. I discussed the terminology related to linguistics and film. I explained what is a multimodal translation, film adaptation, modality, monomodal text, multimodal text, linguistic sign and cinematic sign.

I hope that my work will prove useful, also due to the fact that from the very beginning, linguistics studied both verbal and written statements formulated in only one code. It rarely focused on utterances expressed with several linguistic codes. The exception is the book by Maryla Hopfinger published in 1974 entitled Film adaptations of literary works. Problems of theory and interpretation. In fact, we can see the interaction of all the codes practically at every moment of our lives, e.g. during a conversation between two people, where apart from verbal communication, i.e. one code, there are also complementary facial expressions and gestures additionally reinforcing the message.

\section{References}

Gruszczyk T. (2015), Reading a movie - watching literature, Śląsk.

Hopfinger M. (1974), Film adaptations of literary works. Problems of theory and interpretation, Wrocław.

King S. (1982), Rita Hayworth and Shawshank Redemption and Story from Different Seasons, Hardcover.

King S. (2001), Skazani na Shawshank: Cztery pory roku, Warszawa.

Monaco J. (2009), How to Read a Film: The World of Movies, Media, Multimedia: Language, History, Theory, Oxford.

Post M. (2017), Film as multimodal text. Assumptions and tools for its analysis, Wrocław.

Shawshank Redemption, Frank Darabont, USA 1994

Wildfeuer J., Bateman J., (2017), Film Text Analysis: New Perspectives on Analysis of Filmic Meaning, New York.

\section{DVD disc specification}

The Shawshank Redemption (1994)

Dolby Digital 5.1 English

Dolby Digital 2.0 Polish lector, Spanish, German, French

Subtitles: Polish, Arabian, Spanish, Danish, Dutch, Portuguese, Estonian, Finnish, Norwegian, French, Romanian, Swedish, Turkish,

Subtitles for the Hearing Impaired: English, German

Region DVD: 2 
Number of Discs: 1

Studio: Warner Bros. Home Entertainment

Director: Frank Darabont

Cast: Robbins Tim, Freeman Morgan, Gunton Bob

Running Time: $136 \mathrm{~min}(2: 16: 32 \mathrm{sec})$

DVD Release Date: 2019

Barcode: 7321930949270

Streszczenie

Adaptacja filmowa opowiadania Stephena Kinga Rita Hayworth and Shawshank Redemption (1982) jako przykład wzoru przekładu multimodalnego

Ostatnio spotkałem się ze stwierdzeniem, że ,adaptacja jest serią procesów zachodzących w trakcie przekładu”. Adaptacja obejmuje swoim zasięgiem nie tylko coraz szersze kręgi kina czy sztuki, ale również naszego życia, a samo pojęcie adaptacji ulega ciągłemu rozszerzaniu. Celem głównym artykułu jest pokazanie, że adaptacja filmowa jest przykładem wzoru przekładu multimodalnego. Na skutek tego otrzymujemy zupełnie nowy tekst, jakim jest film w kontraście do jego literackiego pierwowzoru. Aby pokazać, że adaptacja filmowa jest przykładem wzoru przekładu multimodalnego, ujmę ją od strony językoznawczej, co dla niektórych wyda się zapewne czymś nowym. Słowa modalność czy tekst multimodalny będą przewijały się w artykule często. Przy okazji artykułu zaprezentuję też drobną część badań prowadzonych nad filmem od strony językoznawczej w Wyższej Szkole Filologicznej we Wrocławiu.

Slowa kluczowe: przekład multimodalny, tekst monomodalny, tekst multimodalny, znak językowy, znak filmowy 